\title{
TRANSITIONAL AND TRANSFORMATIONAL SPACES: MENTORING YOUNG ACADEMICS THROUGH WRITING CENTRES
}

\author{
Arlene Archer \\ University of Cape Town \\ Email: Arlene.Archer@uct.ac.za \\ Shabnam Parker \\ University of Cape Town \\ Email: PRKSHA034@myuct.ac.za
}

\section{ABSTRACT}

The effectiveness of writing centre interventions on student writing in higher education has been well-documented in academic literacies studies. This paper changes the focus of investigation from student to consultant and, consequently, explores the way in which an academic writing centre can function as a mentoring environment for young academics. As a collaborative learning space encouraging transition and transformation, the writing centre is an important site in which postgraduate student consultants are able to explore facets of their academic identities. The role the writing centre plays in the transition from consultant as student to professional is surfaced through a thematic analysis of interview data. We examine the textures of these transitions and the effect writing centre principles have had on teaching practice with particular reference to dealing with English additional language students and the incorporation of an 'academic development' perspective into mainstream teaching.

Keywords: Writing centres; access to higher education; academic literacies; transitional spaces; mentoring

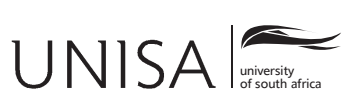

Education as Change www.educationaschange.co.za Volume 20 | Number 1 | 2016 pp. $43-58$
DOI: http://dx.doi.org/10.17159/1947-9417/2016/567 Print ISSN 1682-3206 | Online 1947-9417

(C) 2016 The Authors 
Writing centres are spaces that suspend daily life in order to engage with ideas, prompt new ways of seeing and provide opportunities for reflection. In this kind of 'learning space', the 'values of being are more central than the values of doing' (SavinBaden 2008:8). Learning spaces are often places of transition and transformation, where individuals experience a shift in their perspectives or life worlds. 'Transition' implies movement from one place to another, and can be difficult, but can also be an opportunity for personal growth and change. Writing centres can be spaces that enable this kind of transition and transformation, signifying their liminality in ideation as well as in actualisation.

As a learning space that embraces its sense of liminality, the writing centre is situated in a unique position on the fringe of the university, whilst at the same time functioning as an integral part of the university's centre of academic activity (see Archer \& Richards 2011). The role of writing centres has been conceptualised and reconceptualised at various points. A common initial impetus behind the promotion of writing centres in universities was one of remediation and acculturation of students into academic discourse. Here it was seen as a fix-it shop in the business of changing textual features of writing. Now, writing centres have developed into more processoriented spaces equipped with the task of changing writers. One of the underlying premises of writing centre pedagogy is that a critical way of being develops through discussion and argument. Writing centres are thus dialogic spaces that embrace the complex relationship between the spoken and the written. Bawarshi and Pelkowski's (2003) proposition of postcolonial writing centres as sites that welcome and foster multiple styles, processes and perspectives in writers is one that acknowledges and supports the ideology of the liminal space which in Nichols's (2011) sense is also a safe space. Changes at the level of individuals often lead to changes at institutional level. As Trimbur asserts, 'social justice and the democratization of Higher Education have always been part of the mission of writing centres' (2014:67).

There are many challenges involved in developing and running writing centres in tertiary contexts in South Africa. These challenges include recognising the role writing centres need to play in the acquisition of basic academic literacy practices. They also involve emphasising writing as a mode of learning where higher cognitive functions such as analysis and synthesis are developed through verbal and written language. Academic discourse takes a distinct written form, often comprising unspoken conventions that dictate appropriate uses of lexicogrammatical structures. Each discipline also has its own particular 'dialect'. Acquiring these discourses can prove difficult to many students, not only English Additional Language students. One of the main challenges for writing centres is to provide access to academic and disciplinary discourses through making explicit how texts work in a critical manner, whilst at the same time inducting students into these discourses.

Theorists and practitioners have documented the value of the writing centre's role in successfully assisting students to navigate the murky waters of academic discourse. In South Africa, Lewanika and Archer (2011), Simpson (2011), Dowse 
and Van Rensburg (2011) introduce the idea of shifting the lens from students to consultants in a reflective exploration of the writing centre as a community of practice that works towards shaping and even transforming the academic identities of consultants. For instance, Simpson (2011) expressly explores the development of one particular writing centre consultant in a detailed and nuanced way. He looks at how her understanding of academic writing changes, often through contradictory and dialogic moments in spaces created by the writing centre. The collaborative learning space offers consultants the opportunity to exercise a measure of agency which serves to inform their practices as academics-in-training. These kinds of transitional and transformational spaces are often hidden ones which are sometimes not valued or sufficiently acknowledged by university leadership. This paper aims to explore the contours of these kinds of spaces and how they are realised in writing centres in order to surface some useful teaching and learning practices, and specifically to look at the way in which young academics can be mentored.

\section{WRITING CENTRE DEVELOPMENTAL PROGRAMME FOR CONSULTANTS}

The writing centre at the University of Cape Town employs on average 14 part time student consultants each year (Masters, $\mathrm{PhD}$ and postdoctoral students). There is a strong emphasis on equity, multilingualism and multidisciplinarity in the selection process, and the group is diverse in terms of gender, age, languages spoken and nationality. Because we appoint from a range of disciplines, we are able to access the consultants' disciplinary knowledge, as well as establish strong links to their departments. Our training of the consultants aims to combine the generic and the discipline-specific. In the training programme we examine disciplinary discourses in depth, and the multidisciplinary nature of the group enables unique insight into writing practices. The interdisciplinary nature of the writing centre can thus be seen as a strength rather than a weakness.

We have had a comprehensive training programme since 2000 which aims to build a common writing centre ethos and raise the professionalism of the centre. The 20 hour initial training programme focuses on the theoretical underpinnings of our work, as well as the application of this in everyday writing centre practice. The ongoing training takes the form of weekly seminars, where issues arising from practice are located within a theoretical context. This training includes topics such as multilingualism, English as an additional language, disciplinary discourses, postgraduate issues, multimodality and new media, creative writing, referencing and academic voice. Consultants bring examples of their own disciplinary writing and also interview each other in relation to their own writing processes. The aim of the training is to develop a theoretical basis and common language to talk about teaching, learning and writing processes. 
Since 2005, some of the writing centre consultants have been part of an internationally funded mentoring and bursary programme, the Mellon Mays Undergraduate Fellowship Programme. The long-term objective of this programme is to address the under-representation of black academics in higher education. The programme aims to do this by identifying and supporting students of promise and helping them to become academics of the highest distinction. Consequently, internships were formulated to enable these graduates to advance to postgraduate study through a mentored work-study programme. Programmes like this acknowledge the developmental potentials of the writing centre space, including developing future academics that are attuned to the academic literacy practices of their disciplines.

\section{METHODOLOGY}

Over the years, the writing centre at the University of Cape Town has been successful in developing 25 consultants who have become academics employed at seven different tertiary institutions, well-trained in teaching writing and academic argument. Seven of these were interviewed for the purposes of this research. They come from a variety of academic backgrounds and, at the time of interviewing, were employed across four institutions. Four worked in the field of Academic Development and three were lecturing in their disciplines. Maleson worked in language development, focusing on cultivating postgraduate writing. Anne worked as an Academic Development lecturer in the Department of Construction Economics and Management. Fuad and Nomfundo both worked in Academic Development, augmenting students' academic literacies across disciplinary contexts. Marie was a lecturer in Afrikaans, Joe a senior lecturer in English, Kate a nursing lecturer, researcher and writer.

Vandeyar (2010) has looked at how academics construct and negotiate academic identities in higher education in South Africa. Using narrative enquiry, Vandeyar looked mainly at the construction of narratives of experience, reconstructed through semi-structured interviews. Narrative inquiry is the process of gathering information for the purpose of research through storytelling (Clandinin \& Connelly 2000). Our study is similar methodologically. We too used semi-structured interviews, as well as written reflections. However, we processed the data slightly differently. Vandeyar constructed the narratives of three participants, then analysed them using qualitative content analysis. Since our analysis spanned the interviews and reflections of seven participants, we had less space to reconstruct in depth narratives for each, and rather conducted a thematic analysis across the data. Our methodology is thus one of thematic analysis of the interviews and written reflections. Whilst we acknowledge that these interviews and reflections serve as textual representations of experience rather than ethnographic observations, they nonetheless raise interesting questions around academic mentorship. 


\section{'A FULLSTOP IS JUST A FULLSTOP': DEALING WITH ENGLISH AS AN ADDITIONAL LANGUAGE}

A conceptualisation of the writing centre as a place of remediation often means that students who are considered to be on the fringe of grasping academic discourse are sent to be 'adjusted' according to the accepted ideal. Often, English additional language (EAL) students are propelled to seek assistance at the writing centre at the first sign of academic 'dissonance'. Joe believes that his experience at the writing centre made him 'more sympathetic to the barriers faced by students who are reading and writing in an additional language' (Joe). Kate exhibits shades of the same mind-set: 'I realised that academic discourse can be a major barrier for students, especially students coming from non-English speaking backgrounds' (Kate). She is of the opinion that not enough time is spent on explicitly acclimatising students to specialist academic discourses within the discipline and subsequently the writing centre is commissioned to remedy the situation.

Students are expected to naturally pick up the discourse during their studies, but this does not always happen. Students from non-English speaking backgrounds particularly struggle and this often results in students getting to postgraduate level without understanding the basics of things like referencing and academic argument (Kate).

In an environment where academic writing is the primary means of assessment, struggling with the essential elements of academic writing is problematic for many students. The situation is, however, exacerbated in the case of students with English as an additional language. Nomfundo and Fuad's contact with the quandaries that these students face is particularly revealing. In her dealings with these students, Nomfundo was accosted with the reality that lecturers seem to place a lot of weight on grammar as a component of academic writing. In general, however, writing centre consultants tackle macro issues before micro ones are dealt with. Grammar is attended to after ensuring the argument is clear and whether there is sufficient evidence supporting the proposed argument. However, Nomfundo found that the writing centre's practice of analytically separating the global and local components of revision did not reflect the type of feedback that lecturers give students.

I found that most students would get comments from the lecturer saying you need to go to the writing centre to get your grammar fixed and therefore that was quite a barrier in terms of getting a good mark ... so one of the things that alerted me was that I got a lot of marking practice in different courses, you know, how people mark and the kinds of values I suppose that they operate within as they mark (Nomfundo).

As Nomfundo's exposure to these issues increased, she became more and more critical of the university for accepting EAL students without ensuring the existence of good support structures. She argues that these students tend to know more than their writing exhibits in terms of answering the assignment topic. 
You find that the student knows exactly what goes into answering the essay question and so forth but grammar is such a stumbling block that you know the coherence is absent, everything else is just not there. But if you sit with them ... and you speak to them then it becomes clear that ... this student actually knows what is required ... [but] they get so caught up in the grammar and understandably so because it's preventing them from getting a good mark (Nomfundo).

Sometimes students' writing insecurities are heightened by the comments received from lecturers. When Nomfundo encountered comments such as these, she experienced a combination of frustration at lecturers and empathy with students.

Sometimes the lecturer would put it in a very crude way like you know 'your grammar needs fixing' or you know 'please go to the writing centre because your work is not of a good standard' ... imagine saying that to a first year student who is still trying to find his or her feet in the discourse of the discipline (Nomfundo).

Increased interaction with EAL students and their writing practices can destabilise conceptualisations of what constitutes academic writing. Contestation around plagiarism is one of the issues that surfaced in Fuad's consultations with students. Definitions of plagiarism within the academy are clear-cut but Fuad asserts that with certain students, it 'wasn't plagiarism in the sense [that] "I want to take somebody else 's words and get away with it", it was just purely "I don't have the words"" (Fuad). Socialisation and cultural trends also seemed to play a part in the task of referencing sources. Some students are socialised to believe that it is disrespectful to alter the words of an authoritative figure and, as a consequence, something as seemingly simple as paraphrasing becomes a conflict of interest. The principles of academic writing and by extension, the values of the academy, call the established belief systems of students into question, thereby reinforcing their sense of uncertainty. Fuad cites another example of this observation in action. In reviewing the writing of a Chinese student who had grown up in South Africa, he observed and commented that the student's sentences were extremely long to the point where one paragraph would be made up of one sentence. When enquiring about the trend, the student responded by saying 'from my background if you put a full stop in Chinese it means it's the end of that discussion. The full stop symbolises an ending, not you can elaborate afterwards again'. Fuad's engagement with this student made him realise that the academic writing principle of writing short sentences and elaborating and building an argument may not be so straightforward when other linguistic practices are taken into consideration: 'something like a full stop is just a full stop to me, but for certain students, it's much more than that' (Fuad). 


\section{TRANSFORMATIONAL SPACES: CRITICAL ACCESS TO THE ACADEMY}

Consultants' immersion in the writing centre environment engenders an awareness of the invisible conventions within the academy, including the inner workings of the institution as exemplified in departmental imperatives, the established dynamic between lecturer and student, tutorials and workshops. The writing centre is empty of a fixed content - there is no curriculum and no assessment, and the commitment is to a space rather than to a particular agenda. The notion of a (transformative) space leads to a different conceptualisation than conventional teaching and, for this reason, writing centres can function as agents of change, contributing towards changing the dominant attitudes to language and culture by shifting authority (Nichols 2011). Prior to their induction into the writing centre, consultants acknowledged that some academic practices were relatively uncontested. Marie states that working at the writing centre "forced [her] to know the "rules", it led to a critical look at why these rules are in place and whether they are still relevant or not. Understanding a system better automatically leads to questioning and exploring that system' (Marie).

Discursive practices are ideological in the ways in which they serve to maintain existing relations of power. Kate says that she generally felt that writing was an 'instinctive' process, that she just knew how to write without any direct thought about the process and what it entails. Her training as a consultant gave her insights into the conventions of academic writing and consequently enabled her to give voice to these conventions in a rigorous and logical manner.

I realised that I had not been aware of the subtle 'rules' underlying good academic writing practices. My experience at the writing centre helped me to become conscious of those 'rules' and ... apply them in my own writing and in teaching students to write (Kate).

Similarly, Fuad recounts his initial struggle with articulating implicit knowledge in conversations with students about academic writing and establishes that the writing centre gave me the ability to speak about the reading and writing practices of the university in a more explicit way' (Fuad). In the case of Kate and Fuad, the writing centre experience offered a language in which they could communicate tacit knowledge to students thereby unmasking the hidden conventions of academic writing.

Maleson indicates that the writing centre opened up avenues for alternate ways of viewing institutional practices. He had harboured the notion that when students had learning difficulties, the problem was usually of their own doing. As a consultant, he discovered that 'sometimes when there is a learning problem, the real source of the problem can actually be ... the teaching staff' (Maleson). His approach to students and the academy has subsequently shifted from a top-down model to one that resembles interaction with students on 'a horizontal plane'. Archer has argued elsewhere that effective writing pedagogy involves dialogue between the 
culture and discourses of academia and those of the students, 'offering students from disadvantaged backgrounds an empowering and critical experience, not just bridges to established norms' (Archer 2010b:508).

For those directly involved in Academic Development, progressing from the writing centre into their chosen specialisations is a matter of continuity. For the rest of the consultants, an 'academic development' perspective enhances their academic teaching practice insofar as they are more aware of some of the tacit issues that permeate the lives of students. This awareness has led to a conscious effort amongst those interviewed not to let established assumptions rule their practice.

Fuad's classification of 'the struggling student' underwent a transformation. Fuad reveals that he always had a desire to work with disadvantaged students, that is, those he perceived to be on the fringe of university life. The writing centre as a space occupying border residency in the grand scheme of academic citizenship provided Fuad with the impressions of who comprised the margins. The reality was much more complex than he had imagined.

I thought of township students, second language, but it's much more than that. It can be first language, advantaged background, very good school, still can't survive and why not? What's happening? So ... the mentoring space of the writing centre also got me out of that idea of 'it's only this type of student who struggles' ... it's not just only ... township students, it's not just second language whose struggling, most students struggle at university with writing (Fuad).

This exemplifies the extent to which writing centre consultants are in a liminal space, somewhere between students and professionals. The power structures become apparent in these kinds of liminal spaces, in-between being students and lecturers.

While Maleson and Fuad reflect on particular subsets of the academic community, Anne looks at the situation more broadly suggesting that her positioning as a consultant encouraged self-reflexive engagement with the institution and its academic practices. She explains

by sitting in the writing centre you're looking at academic writing from the outside so you become quite critical of those forms of writing and what the purpose of those forms are and the way they are constituted within the university and the practices within the university including your own discipline wherever that might be. I mean, I became more aware of academic writing practices as a sort of phenomenon (Anne).

In their vision of the postcolonial writing centre, Bawarshi and Pelkowski (2003:8890) conjure up the idea of a mestiza consciousness as one that is 'marked by the ability to negotiate multiple, even contradictory, subject positions while rooted in the dominant discourse'. One of the goals of the writing centre is to help marginalised students and writers achieve this consciousness. Consultants, as seasoned writers and practising academics, engage in these multiple subject positions as evidenced by the transformations apparent in the narratives of Maleson, Anne and Fuad. They 
seem to have embraced the ideology of a mestiza consciousness in a postmodern sense by recognising and reflecting on accepted norms and destabilising them in the process. Furthermore, by employing a critical 'academic development' perspective in their respective disciplines and teaching methods, consultants-turned-academics are better equipped to deal with the complexity of academia and effect change where it is warranted.

\section{STUDENT-CENTRED PEDAGOGY: HOW ONE-TO-ONE FEEDS INTO THE CLASSROOM}

The cognitive as well as the affective value of the one-to-one consultation is welldocumented (Archer 2008; Harris 1995) and the walk-in nature of writing centres is seen as important in meeting students' immediate needs which may not be met in individual departments. The premise underlying the one-to-one consultant-student relation is Lave and Wenger's argument that learning is located in increased access of learners to participating roles in expert performances (1991:17). Also, that writing is learnt 'implicitly through purposeful participation, not through instruction' (Ivanič 2004: 235).

While consultants like Anne and Joe acknowledge the value of the one-to-one strategy, as mainstream academics the conflict between this form and traditional modes of teaching is slightly more difficult to navigate within their specialist disciplines. For Joe, students 'may have their own academic, personal or other problems but unless they contribute in class or approach me separately, they remain simply names and faces rather than individuals' (Joe). Anne contends that while she continually strives towards making the individual explicit in her teaching practice, there is a sense that her role in the academic community has shifted:

Now that I'm a lecturer I actually tend to lead more. In the writing centre it's peer- to-peer, but here I think maybe the students expect more, more direction from me, but also maybe I feel that I have more of ... a discipline or content knowledge so that I can guide them better as well ... guide them more specifically (Anne).

Maleson, Nomfundo, Fuad and Marie paint a different picture of the transition from consultant to academic, emphasising an approach that is student-centred rather than teacher-centred. Maleson draws attention to the notion of 'the ideal student' which is an imagined construct that lecturers and other academic staff use as a shorthand when dealing with a mass of students. In comparing the tenets of one-to-one practice to his own teaching methods, Maleson states that

the ideal student is able to do ABCD. And everyone must fit into that model which I have in my head about what the ideal student is like. So, that's the kind of construct which I think is deconstructed when you work at the writing centre ... because you begin to understand, look 
a lot of students don't fit into that ideal. So when you go back to teaching a mass, I think you are more sensitive again of individual differences within the mass (Maleson).

While lecture theatres filled with large numbers of students are not likely to disappear from the academic landscape, Fuad asserts that 'yes, it's about a whole class of students but now the one-to-one teaches you about the individual as well ... the oneto-one has shown me that you first have to have a real human understanding before that academic stuff comes into play' (Fuad). In his practice as an academic, Fuad consciously highlights the difference between lecturing and mediating. The former is posited as a hypodermic transmission of knowledge whereas the latter is a style of teaching that 'is about trying to take a student from a certain point to another point of progress' (Fuad). This view of writing as a process and a social practice involves a shift from thinking of writing as an individual possession or 'skill' (Lea and Street 1998), towards the notion of an individual engaged in socially situated action, writing in specific disciplinary contexts (Lillis 2001:31). Writing is not only what people do, but rather what they understand of what they do and 'how it constructs them as social subjects' (Clark and Ivanič 1997:82). This notion of academic writing as a social practice encapsulates the 'academic literacies approach' (Lillis and Scott 2007:11) of our writing centre.

Fuad refers to the writing centre as an in-between space, one that is between the university and the student, between the novice consultant and the practising academic, between absolute despair and mediating confusion through communal meaning-making. For Fuad, the writing centre as a space that focuses on the student enables 'meaning-making to happen between student and consultant ... it's getting into the confusion' (Fuad) and aiding the student in the quest for academic success. Nomfundo reiterates this idea of empowering students when she recounts that the benefit of the one-to-one experience is that it gives students the space to speak: 'the consultation taught me that it's not ... like you are talking at the student ... there is a conversation that's happening between the two of you' (Nomfundo). This right to 'speak, to be entitled to speak and to share our perspectives is a vital space in academic life' (Savin-Baden 2008:65).

\section{OWN RESEARCH AND WRITING PRACTICES: IDENTITY AND VOICE}

Consultants claim that working in the writing centre environment has enhanced their understanding of academic writing practices through uncovering the hidden 'rules' as discussed earlier, engaging in debate with fellow writers or gaining writing experience through interaction with students. Maleson introduces the idea of 'writing vicariously' when discussing how his engagement with students' texts influenced his own writing practices. He acknowledges that engaging with various texts across the disciplinary spectrum and with students with differing individual needs 'feeds back 
into your own writing, into the way in which you understand the practice of writing' (Maleson). Maleson believes that his awareness of and interaction with these various genres within the parameters of academic writing has allowed him to write with a sense of collective or shared writing experience.

I write like somebody who has a lot of experience with writing ... but the interesting part I think is that the experience I have with writing is not ... experience that has come from my own writing. It's almost like I've gained experience by looking at the writing of other people (Maleson).

He claims that each time a student brings in a piece of writing, the consultant endeavours to revise the text with the hope of improving it in collaboration with the student. As a consequence, the consultant is directly involved in the writing exercise and through this involvement practises the art of academic writing, which in turn impacts on their own writing. Maleson concludes by intimating that 'I think I've become a much more mature writer and a much more ... lucid writer than I was before' (Maleson).

Nomfundo, Anne and Fuad also see the experience of working in the writing centre as having encouraged their transformation as writers. For Nomfundo, it was a case of practising what she was preaching: 'I couldn't talk about good structure and then go and do something different in my own thesis ... so what I was actually saying to the students in consultations and in the workshops was shaping how I was writing my own thesis' (Nomfundo). As a second language speaker herself, grammar has always been a sticky issue. Nomfundo narrates that because incorrect grammar had an effect on the readability of written assignments, she was often trapped in the minute details of word structure and how this aligned to form grammatically correct sentences. However, in advocating the principles of academic writing in the capacity of a consultant, Nomfundo learnt to put writing concerns into perspective. While she recognises the importance of grammar in the project of writing, she values the fact that working in the writing centre 'taught [her] to foreground structure over grammar' (Nomfundo). This change in standpoint enabled her to view writing in a more holistic way, helping her to structure the arguments in her thesis in a comprehensible manner without being caught up in micro grammatical considerations. Nomfundo admits that the principle of writing bigger than grammar was a constructive one because 'it had very good rewards for [her] research as well' (Nomfundo). Nomfundo's approach to academic writing thus underwent a change in strategy that was beneficial to her practice as an academic.

The writing centre as a 'transitional space' enables shifts in learner experience to occur. These shifts can be caused by 'a challenge to the person's life world in particular areas of their lives at different times in distinct ways' (Savin-Baden 2008:108). Whilst working with student writing, Fuad experienced a transition that added nuances of complexity to his writing that were previously absent. Fuad 
recollects that at the time of writing his Masters' thesis, he presented his arguments in quite absolute terms.

I would say my argument is this and I disagree with this ... I was always polarised and stuff, I don't agree with that, I disagree with you. Then, I started to see how certain modals and certain words like 'some theorists have argued that' and shifts like 'also', 'however' ... I became acutely aware of them, and I started to write very carefully. I sounded very confrontational in my Masters and now with the $\mathrm{PhD}$, I'm much more tentative (Fuad).

Fuad's consultations with students were one of the primary avenues through which he recognised the extent to which his own writing was polarised. The confrontational stances present in some of their writing alerted him to the aggressive tone in his own writing. Accordingly, Fuad sought to make a change in his own writing, and while the transition is tentative, it is also more gratifying.

It's just become much more complex, but in a good way. It's not debilitating. It really makes me think about things and I've asked myself continuously, who's writing here? Is it me? Do I see myself in the text? Whereas before, I would ... read my Masters and say that sounds like James Gee, that sounds like so and so, now when I read, I can say this is actually me. This is something that was built in that writing centre, a certain type of writer that I wasn't aware of before (Fuad).

The writing centre helped foster an academic that writes and thinks beyond the linear tropes of polemical certainty. In a sense, working in the writing centre environment challenged Fuad to question his own position in relation to his writing and thus afforded him the tools required to transition from confrontational fixity to exploratory complexity.

\section{'HOME AWAY FROM HOME': WRITING CENTRE AS COMMUNITY}

Writing centres have a strong sense of community and of the value of the individual. In this sense they are not 'centres' so much as safe houses (Canagarajah 2004) - extracurricular spaces that provide nurture and exist apart from and outside of surveillance by authority. Chihota (2007) reflects on how postgraduate writers' circles in a writing centre enable a space of supportive playfulness where students are able to try out 'graduateness' in a low stakes environment. Students need such spaces to practise being academics. As Vandeyar points out, the formation of academic identities is largely 'defined by power relations inherent and characteristic of an institution; the intricate and subtle workings of which play a pivotal role in affirming or negating academic identities' (2010:932).

For many of the consultants, the sense of collegiality that permeated the space provided a welcome measure of security. Anne, Maleson, Fuad and Joe allude to the solitude of the postgraduate experience and the writing centre as a space that 
engenders dialogue between peripheral figures, offering a site where those on the fringe feel at home. When deciding to apply for the post of writing consultant, the idea of belonging to some form of a community appealed to Anne: 'it sounded like I'd get a chance to meet people 'cause I was struggling to meet people on campus ... I didn't know anybody on campus at all when I first took up the job'(Anne). At the time, Anne had already commenced the second year of her PhD.

The sentiment of academic isolation and the need for companionship with a group of peers is well-expressed by Joe.

Being a postgraduate student who was teaching part time, I typically felt that I was on the 'fringe' of the department in which I was based. While working at the writing centre I felt that I was a valued colleague of my fellow-consultants and others. This collegial atmosphere-in meetings, in a professional capacity or casually_was encouraging (Joe).

Lewanika and Archer (2011:152) contend that 'besides combating the isolation of postgraduate study, a community of practice like the writing centre helps to define an academic identity'. It is evident that the writing centre fosters a sense of collegiality amongst consultants and works towards cultivating their academic identities in a myriad of ways, most notably by creating a sense of belonging. Maleson relates the experience as akin to a homecoming: 'when I came into the writing centre it's like I identified with a certain closely knit group or a closely knit community ... and it almost became like my home away from home' (Maleson).

\section{FINAL COMMENTS}

Scott (2009:5) argues that 'the great majority of the educated and skilled people needed to take a country forward must be grown at home. While Higher Education has a range of roles in developing societies (not least the creation and application of new knowledge), producing good graduates is its central and unique responsibility'. In grooming consultants, the writing centre not only contributes to this responsibility but also actively encourages the production of good academics. Maleson refers to the writing centre as a 'seedbed' for future academics.

Their academic experience means that all consultants had some prior induction into academic discourse and institutional practices before joining the writing centre. Nevertheless, all commented on the significance of the writing centre to the development of their pre-existing ideas of academic discourse, particularly the barrier that this specialised discourse can pose to English additional speakers. Of importance was the access and exposure that the writing centre gave the consultants to academic literacies, both in a theoretical and practical sense. In addition to academic discourse, consultants felt they benefited from their writing centre experience insofar as it improved their own research, writing and teaching. It did this by allowing them to appreciate a wide number of different disciplines, to become explicitly aware of the 'rules' that they took for granted in their own writing and to shift the focus of 
their teaching from 'teacher-centred' to 'learner-centred'. The specific experience of one-to-one teaching in the writing centre was beneficial in this regard. The writing centre was considered by all consultants as a critically important space for mentoring new academics.

What was beyond the scope of this paper, but would be most useful for future research, is the exploration of the potential of writing centres as transformative spaces for the institution more broadly. Of interest would be to explore the tutors' teaching practices beyond the writing centre, in mainstream lectures and tutorials. Future research in this area could look at the ways in which writing centre trained academics transfer aspects of writing centre pedagogy into mainstream teaching.

This paper has argued that there is a link between a particular learning space and the creation of an academic identity. A writing centre can play a central role in mentoring young academics through its unique positioning in the institution, its interdisciplinary nature (which needs to be reconstructed as a strength rather than a weakness), and its demonstrated ability to create coherent communities of researchers and writers. One of the underlying premises of writing centre pedagogy is that a critical way of being develops through discussion and argument. Writing centres are thus dialogic spaces that embrace the complex relationship between the spoken and the written, and how the written is understood by a reader. Transformation results through engaging in dialogue. Unfortunately, changes in academic life such as shifts towards performative practices and accountability have increasingly resulted in a regrettable reduction in dialogic spaces. It is thus imperative to recognise the value of such spaces as writing centres where contesting knowledge and subject positions are foregrounded, where interrogation within and across disciplines can occur, and even where the fabric of higher education can be questioned.

\section{ACKNOWLEDGEMENTS}

We are indebted to the commitment and insights of the seven interviewed consultants, as well as Cheng-Wen Huang for assisting with interviewing. In addition, we would like to acknowledge the financial support of the National Research Foundation (NRF) and the University Research Committee at UCT.

\section{REFERENCES}

Archer, A., \& Richards, R. 2011. Writing centres as alternate pedagogical spaces. In A. Archer \& R. Richards (Eds.), Changing spaces: Writing centres and access to Higher Education in South Africa, 5-16. Stellenbosch: Sun Media.

Archer, A. 2010a. Multimodal texts in Higher Education and the implications for writing pedagogy. English in Education 44(3):201-213. 
Archer, A. 2010b. Challenges and potentials of writing centres in South African tertiary institutions. South African Journal of Higher Education 24(4):495-510.

Archer, A. 2008. Investigating the impact of writing centre intervention on student writing at UCT. South African Journal of Higher Education 22(2):248-264.

Bawarshi, A. \& Pelkowski, S. 2003. Postcolonialism and the idea of a writing centre. In J. Murphy \& S. Sherwood (Eds.), St Martin's sourcebook for writing tutors. Second Edition. Boston: Bedford/St Martin's.

Canagarajah, S. 2004. Subversive identities, safe pedagogical houses, and critical learning. In B. Norton \& K. Toohey (Eds.), Critical pedagogies and language learning. Cambridge: CUP.

Clandinin, D. J. \& Connelly, F.M. 2000. Narrative inquiry: Experience and story in qualitative research. San Francisco: Jossey-Bass Publishers.

Clark, R. \& Ivanič, R. 1997. The politics of writing. London and New York: Routledge.

Chihota, M.C. 2007. 'The games people play': Taking on postgraduate identities in the context of writer's circles. Journal of Applied Linguistics 4(1):131-136.

Dowse, C. \& Van Rensburg, W. 2011. 'Conversations' with postgraduate writers: Understanding the role of the peer tutor. In A. Archer \& R. Richards (Eds.), Changing spaces: Writing centres and access to Higher Education in South Africa, 159-176. Stellenbosch: Sun Media.

Harris, M. 1995. What's up and what's in: Trends and traditions in writing centers. In C. Murphy \& J. Law (Eds.), Landmark essays on writing centers, 27-26. Davis: Hermagoras.

Ivanič, R. 2004. Discourses of writing and learning to write. Language and Education 18(3):220245.

Lave, J. \& Wenger, E. 1991. Situated learning: Legitimate peripheral participation. Cambridge/ New York/Victoria: Cambridge University Press.

Lea, M.R. \& Street, B. 1998. Student writing in higher education: An academic literacies approach. Studies in Higher Education 23(2):157-172.

Lewanika, T. \& Archer, A. 2011. Communities of practice: Reflections on writing, research and academic practices in the UCT writing centre. In A. Archer \& R. Richards (Eds.), Changing spaces: Writing centres and access to Higher Education in South Africa, 147-158. Stellenbosch: Sun Media.

Lillis, T. \& Scott, M. 2007. Defining academic literacies research: Issues of epistemology, ideology and strategy. Journal of Applied Linguistics 4(1):5-32.

Lillis, T. 2001. Student writing: Access, regulation, desire. London and New York: Routledge.

Nichols, P. 2011. A snowball in Africa with a chance of flourishing: Writing centres as shifters of power in a South African university. In A. Archer \& R. Richards (Eds.), Changing spaces: Writing centres and access to Higher Education in South Africa, 91-100. Stellenbosch: Sun Media.

Savin-Baden, M. 2008. Learning spaces. Creating opportunities for knowledge creation in academic life. Maidenhead: Open University Press.

Scott, I. 2009. Towards an agenda for SoTL in Africa? International Journal for the Scholarship of Teaching and Learning, 3(1). Available: http://digitalcommons.georgiasouthern.edu/ijsotl/ vol3/iss $1 / 3 /$ 
Simpson, Z. 2011. Becoming a writing centre consultant: Effecting change on the part of a postgraduate student entering into the consultant experience. In A. Archer \& R. Richards (Eds.), Changing spaces: Writing centres and access to Higher Education in South Africa, 177-190. Stellenbosch: Sun Media.

Trimbur, J. 2014. Multiliteracies, social futures and writing centers. In S. Lee \& R. Carpenter (Eds.), The Routledge reader on writing centers and new media, 66-68. New York and London: Routledge.

Vandeyar, S. 2010. Shifting selves: Constructing and negotiating academic identities. South African Journal of Higher Education 24(6) 914-934.

Van Rensburg, W. 2004. The discourse of selfhood: Students negotiating their academic identities in a writing centre: Reading, writing, translation. Journal for Language Teaching 38(2):216228. 